chemist in the schools of physies of Oxford and Cambridge, and it is now a very highly developed part of his equipment. His work is characterized also by great, versatility in the use of isotopes, particularly in the elucidation of the course of chemical reactions in the inorganic, organic and biochemical fields. These activities are well integrated, and they will be brought to bear most effectively in his new post as professor of ehemistry and director of the Laboratories at Auckland University College.

\section{British Museum (Natural History) :}

The Neolithic Revolution

In the Central Hall of the British Museum (Natural History) in South Kensington the series of displays illustrating the evolution of man and his eulture has been extended by the arrangement in Bay 4 of a new exhibit on the "Neolithic Revolution". The exhibit deals primarily with the biological foundations of Neolithic culture: Panel 1 with the beginnings of plant cultivation; Panel 2 with the domestication of animals (dogs, goats, sheep, cattle and pigs) ; Panels 3 and 4 with related activities, including hunting and fishing with the aid of new devices, the mining of flint, the manufacture and trading of polished stone axeheads, their use in the clearance of forest for agriculture, the construction of permanent dwellings, the formation of villages, and the development of specialized crafts such as basketry, the making of pottery, and the spinning and weaving of plant and animal fibres for use in clothing. The probable relation of Neolithic religious ideas to agriculture is indicated. Specimens shown on the panels have been drawn from a wide range of Neolithic sites, including Jericho, Jarmo (Iraq), and others in Egypt, Sudan, Switzerland, Denmark and Britain-notably Windmill Hill (Wiltshire), Maiden Castle (Dorset), Church Hill, Findon (Sussex), and Grimes Graves (Norfolk). The first panel includes examples of some of the earliest cultivated plants (einkorn and emmer wheat, flax and the Celtic bean) recently grown under Neolithic conditions on a private experimental plot in Kew Gardens. The exhibit demonstrates some of the contributions of the natural sciences (particularly botany, zoology and geology) to archæology ; and it indicates the biological interest of many of the findings of archæological research.

James Sowerby (1757-1822)

ANother new exhibit has also been arranged in Bay 4 of the Central Hall of the British Museum (Natural History) to commemorate the work of James Sowerby, the founder of a family whose members have been distinguished as authors and illustrators of natural history works, and who between them wrote and illustrated more than seventy works on botany, zoology and palæontology. James Sowerby, born in 1757, studied with the marine painter, Richard Wright, and was later employed by William Curtis to make drawings for the Flora Londinensis and the Botanical Magazine. Sowerby, however, is probably best known for his plates to the "English Botany" (1790-1814), the text of which was written by Sir J. E. Smith, though the work is generally referred to as "Sowerby's English Botany". Sowerby was also deeply interested in mineralogy, and his "Mineral Conchology of Great Britain" (1812-46) is a work of considerable historical interest. An unfinished zoological work, "The British Miscellany" (1804-6), contains as its first plate a figure of
'Sowerby's Whale', described and figured by the artist from a specimen found near Elgin in Scotland. The Museum possesses the original water-colour drawings for the "English Botany", more than 2,500 in number, the originals of the "English Fungi" (1795-1815), and the drawings to illustrate J. Dickson's "Fasciculus Plantarum Cryptogamicarum Britanniae", Fase. 2-4 (? 1789-1801). A selection of these, together with some of Sowerby's published works, are on exhibition, and give some indication of the great talent and wide scientific interests of this famous artist-naturalist.

\section{Illinois Journal of Mathematics}

THE pressure on scientific periodicals is still so great that new journals are bound to be welcome, except possibly to those librarians to whom space is already a problem. The new Illinois Journal of Mathematics, published by the University of Illimois, Urbana, has a strong editorial board consisting of R. Baer (Frankfurt-am-Main), J. L. Doob and A. H. Taub (University of Illinois), G. W. Whitehead (Massachusetts Institute of Technology) and $O$. Zariski (Harvard). It will publish research papers in pure and applied mathematics, written in English, French, German or Italian. A volume of four quarterly parts will cost 9 dollars, but there is a reduced subscription available to members of the American Mathematical Society. The first part (March 1957) contains ten papers in its 114 pages; most of these are fairly short, with an algebraic and topological flavour, but there is a first instalment (50 pages) of a three-part memoir on Markoff processes and potentials. It will be of interest to see whether the new journal can attract good work on applied as well as on pure mathematics.

\section{British Birds}

EARLY in 1907 H. F. Wetherby persuaded a number of friends and ornithologists to support a monthly magazine devoted entirely to the study of British birds. The fiftieth anniversary of British Birds is now being celebrated, and its latest issue $(50$, No. 6 ; June 1957) tells the story of its steady rise in influence and quality until, as the messages from many countries indicate, the journal is now recognized throughout the world as an outstanding contribution to ornithological literature. Greetings which must give particular pleasure to the editors include that from Tom Harrisson, curator of the Sarawak Museum, and Prof. G. P. Dementiev, of the University of Moscow, a confessed admirer of British Birds for thirty years. The journal has always been noted for the quality of its plates, and this birthday issue contains a reproduction of a painting of collared doves (Streptopelia decaocto) by R. A. Richardson which is worthy of its predecessors; so, too, are some photographs by, among others, Eric Hosking, James Alder and J. H. Drenth. British Birds is to be congratulated on its first half-century of existence; and may look forward to the second half-century with confidence.

\section{Zoological Libraries}

ZoolOGICAL libraries are the subject of the sixth in the series of publications on Library Resources in the Greater London Area, issued by the Library Association (pp. $\mathrm{ii}+21$. London, 1957. 4s. 6d.). Compiled by A. C. Townsend and G. B. Stratton, the pamphlet deals chiefly with the British Museum 